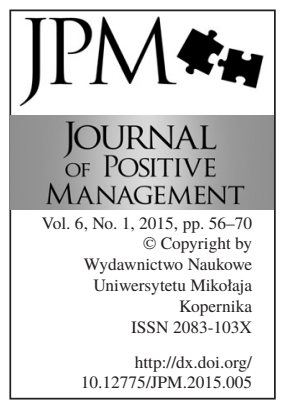

\title{
GROUP PURCHASING ORGANIZATION \\ (GPO) AS A MEANS OF BUSINESS COSTS SAVINGS
}

\author{
Joanna Piorunowska-Kokoszko \\ Faculty of Management, University of Lodz, Lodz, Poland, \\ e-mail: jkokoszko@komandor.pl
}

\begin{abstract}
Purpose: The main purpose of the paper is to introduce group purchasing organizations (GPOs) and elaborate on their role as a savings generating factor in reconfiguration of the supply chain.

Approach: The basic methodological approach profited from in this article is descriptive and has been based on literature (mainly scholarly articles), business reports and a case study.

Methodology: Literature study, and an analysis of a case study of one of the Polish purchasing group against the background of topical academic research and business reports.

Implications for society: The article is aimed at showing a new way of optimizing operational costs and thereby create new employment possibilities.

Value of the paper: The main value of the article lies in the acknowledgement of appearance in Poland of a new business structure which allows, without excessive expenditure on the part of an enterprise, to lower operational costs and thereby improve cost-effectiveness of the business.
\end{abstract}

Keywords: purchase, purchasing strategy, purchasing group, business savings

Paper type: General review

\section{Introduction}

Modern enterprises permanently seek solutions able to effectively reduce their operational costs since these are the business expenses which have become one of the most important elements to be managed by entrepreneurs. Accordingly, buying departments of every company look for solutions limiting cost figures and allowing to generate extra savings in the field of both strategic (i.e. connected directly with the operational activity, e.g. raw materials and marketing costs) as well as non-strategic purchase expenditure, because its reduction, by even small percentage, leads to noticeable financial effects. Moreover, contrary to labour cost cuts, achieving purchase savings does not cause internal conflicts in the company.

While large companies use for that purpose strategic sourcing, small enterprises often create the so-called group purchasing organizations (GPOs), 
which are sometimes also known as purchasing consortia. They are a relatively new element in the supply chain of Polish companies.

A GPO is an entity that is created to leverage, on the basis of the collective buying power of GPO members, the purchasing power of a group of businesses in order to obtain discounts from vendors. As a result participation in purchasing groups permits to reinforce the bargaining position towards suppliers and thereby to obtain more beneficial conditions for cooperation and in consequence to lower costs of the companies belonging to the consortium. Such form of partnership is popular both in the private as well as in the public sector.

Given the scale of the phenomenon, no wonder that this problem has been recently discussed not only in business but also in academic circles. For instance, the issue was elaborated on by M. Essig, (Essig, 2000) J. Nollet and M. Beaulieu (Nollet and Beaulieu, 2005) Y. Polychronakis and A. Syntetos (Polychronakis and Syntetos, 2007) or E. Tella and V.M. Virolainen (Tella and Virolain, 2005) and other researchers. Generally, the authors show that a success in establishing cooperation in the area of purchasing provides a strong chance to build strength of companies and that an efficient group purchasing organization can be the key element contributing to the competitive advantage of the businesses involved therein.

On the other hand, there are also opinions that purchasing groups are a very controversial solution (Arend and Wisner, 2005; Hong and Jeong, 2006). For example, H. Ghaderi and Z. Leman (Ghaderi and Leman, 2013) think that reduced cost of purchase and shorter time of delivery, leading to a decrease in purchase expenses and the optimum selection of raw materials, are, undoubtedly, advantages of this form of cooperation, however, these factors do not, in fact, play the main role in the success of such group, because mutual confidence and efficient supervision are equally significant factors a GPO's economic viability, and those, seemingly simple to achieve, collaboration elements are genuinely difficult to establish, often resulting in a failure of the undertaking.

Nonetheless and in spite of the listed problems, GPOs have established themselves firmly in the supply chain of European companies because of all the companies' consistent efforts to find economically viable solutions to increase the profitability of their operations (Leddy, 2002).

In order to elucidate the phenomenon, the article will, first, describe the origins of the group purchasing organizations, and, subsequently, explain, based on collected secondary data, what possible savings are able to be achieved as a result of entering a GPO cooperation scheme irrespective of the size of a company.

\section{History \& development of GPOs}

In the literature the observed increase in the number of group purchasing organizations has been compared to sharing economy [1]. This idea was assessed to be economically viable for cooperation in the field of purchase or distribution
GROUP PURCHASING ORGANIZATION (GPO)

Joanna

Piorunowska-Kokoszko 
GROUP PURCHASING ORGANIZATION (GPO)

Joanna

Piorunowska-Kokoszko and the trend is called in literature sharing purchase or sharing distribution (Aigrain, 2012). In the light of the theory, a group purchasing organization is an alliance of companies conducting a consolidated purchase scheme by means of a joint entity. Purchasing consortia go by many names, including purchasing groups, group purchasing organizations, federal organizations of purchasing, and international purchasing organizations. However, they all have analogous goals, differing mainly in their structure, vertical focus, and modus operandi [2].

Activities of such a group are based on the mechanism of negotiating better financial conditions of supplies purchase, resulting from a larger volume of the buy (economies of scale) and an ensuing stronger pressure on suppliers, what leads to reducing costs of transactions. According to L.R. Burns (Burns, 2012) group purchasing organizations are structures providing a critical financial advantage to providers by negotiating purchasing contracts for products and non-labor services. A typical GPO has many organizations as its members and profits from this collective buying power in negotiating contracts with many suppliers. The contracts last usually from three up to five years, giving providers price protection.

According to K. Kolińska and D. Doliński (Kolińska and Doliński, 2013) a group purchasing organization is a voluntary association of few or more enterprises, carrying out together the purchase of products and services on different markets, where the consolidation of demand provides favorable conditions for their transactions. Such groups can develop purchasing power for the benefit of:

- a corporation, e.g. Colgate Procurement Group (USA) or Chrysler Purchasing Group;

- a sector, e.g. Health Trust Purchasing Group (USA) or Hospital Corporation of America;

- or various companies from different sectors - an inter-sectorial organization plays the role of a typical outsourcing company, e.g. The Procurement Group (UK), purchasing for their members energy, telecommunication and banking services, office materials etc.

According to this classification there are essentially three types of a consortium/GPO:

- companies within the same industry sector forming a 'vertical' consortium;

- companies from different sectors, constituting a 'horizontal' consortium;

- and finally, the "master buyer', which is a large, multinational corporation, profiting from its various elements to form a supply chain for other companies.

S. Khalid (Khalid, 2014) shows that, when compared with smaller ones, larger companies make much better use of consortia and utilize them more effectively. It is to be added that a 'small' company is defined by the author to have 1.000 or fewer employees, a 'mid-size' one is said to employ at least 1.000 
but fewer than 5.000 people, with any company employing over 5.000 people being defined as 'large'.

It is also undeniable that the sector of GPOs, with their accumulated negotiating power, allows for faster and more effective achievement of better purchase conditions than in the case of an individual company, which is shown in such indicators as lower buying prices, better conditions of service, and the standardization of the assortment. Moreover, apart from measurably more favorable economic conditions of purchasing, GPO members can get other benefits, such as transfer of knowledge and innovation (Bartkowiak and Domański, 2013).

The first group purchasing organizations were established in the 1950s. It is important to recognize that GPOs were originally formed to bring together buyers and sellers in order to create a more efficient marketplace (Schneller, 2009). The largest growth in the number of GPOs took place in the eighties and nineties of the XXth century (Weinstein, 2006). Many of those eventually merged in the mid-1990s to form larger organizations (Scanlon, 2002). Currently in the USA a decision to join a GPO is treated as a usual step of companies' management. There are a lot of GPOs active on the American market, for instance the Global Purchasing Group [3], the Colgate World of Care Procurement Group [4] or, working for health care sector, the HealthTrust Purchasing Group. In Europe purchasing consortia have existed since the XIIth century. The Hanseatic Union, unifying Scandinavian, German and Dutch cities, is commonly regarded as a first form of a European GPO, and cities collaborating in the Hansa, decided on joint trade (purchase and sale), what constituted the ovule of today's purchasing organizations [5]. In the XIXth century in Germany Friedrich Wilhelm Raiffeisen (the Raiffeisen Genossenschaft) and Hermann Schulze-Delitzsch (the Volksbanken Financial Cooperatives) were precursors of activities integrating cooperative movements, while the first cooperative for retail trade, i.e. Konsumgenossenschaft, was created in 1850 (Knoben and Sawiński, 2014). Nowadays, GPOs in Germany, e.g. the Prospitalia $\mathrm{GmbH}$, representing more than 580 partners, or the Agkamed $\mathrm{GmbH}$, associated with 158 hospitals, work mainly for the health sector. However, it is France, with its GPO network implementing joint purchase for hospitals (covering 35-40\% of the demand), which is considered to achieve the position of the most advanced European country in terms of GPOs' market presence. In Great Britain purchasing consortia, e.g. the Utilities Procurement Group, are present especially in the energy sector [6]. Over the last few years, in Europe, not only the general interest in the GPO sector has been rising. So have been risen turnovers of the majority of GPOs. For instance, the EMD group boasts an annual turnover of over 120 billion euro, while the second place has been allotted to the Carrefour network, with the income equivalent to the 101 billion euros annually (in terms of the retail trading value), while the third place has been won by the Coopernic
GROUP PURCHASING ORGANIZATION (GPO)

Joanna

Piorunowska-Kokoszko 
GROUP PURCHASING ORGANIZATION (GPO)

Joanna

Piorunowska-Kokoszko
Group, created from the initiative of the E. Leclerc, namely the REWE, and the Swiss cooperative tycoon, namely the Coop Suisse, whose incomes amount to approximately 100.5 billion euro [7]. In Asia, in turn, GPOs have focused on the high-tech sector and they mainly purchase sub-assemblies from the largest Asian equipment manufacturers such as the FujiFilm, the Hitachi or the Asia Pacific Utilities Group [8].

In Poland, GPOs are a relatively new solution, which seems to be apparently attractive, however, at the same time, a little problematic, because of its lack of national legal regulations which would allow to keep financial regime and forecast trends. Presently, there are a number of GPOs, divided into regional or countrywide ones. The second type includes participating companies from the entire country and give them a chance of receiving discounts of several percent (for example, the BATNA Group S.A. [9], dealing in fuel supplies, office equipment, medical services, electric energy distribution, telecommunication services etc.), while the regional ones (for instance, the Polish Shops Group PASSA, working with 250 suppliers and manufactures) have set for cooperation with local salesmen and, can offer (generally lower) discounts of 5-8\%. As for sectorial phenomena, we can observe a rapid growth in the number of GPOs in health care, with the Polish Hospitals Federation, the Termedia and the Supra Group as the leading ones. The idea of GPOs have also become more popular with local self-government units, which trend can be exemplified by means of the Lódź Purchasing Group, consisting above 5000 partners, whose activities in 2014 resulted in 8 million PLN savings on energy for those participating in the group [10].

It is obvious that participation in GPOs, just as every solution, has both advantages and disadvantages. The benefits of being a member of a GPO are:

- keeping the independence of business;

- access to new suppliers of goods and services thanks to contacts of the group;

- possibility of the extension of the current offer;

- lowering prices of goods and services (from a few up to a dozen percent, which contributed to the improvement in the profitability of the company);

- minimization of the risk of shipment of goods as a result of the fact that the cooperation takes place with the distributors whose reliability has been checked by the group;

- the improvement of competitiveness;

- time savings on building relationships with the suppliers (a GPO can save a company's time and effort spent on negotiations by means of making available to it an advantageous contract);

- and finally a GPO provides its members with access to specialists (who are obliged to help in case of trouble, train in sales and business activities, and supply them with both product information and standardization, 
i.e., comparison shopping and best combinations of cost and quality for demanded products).

Disadvantages of using a GPO are not as numerable.

- First of all, the participation in a GPO can reduce the amount of control the purchasing department of an enterprise has over its purchasing decisions.

- Secondly, it can require an investment that may not be recouped if you are unable to get end users to use the GPO contracts.

- Last but not least, it can show weaknesses in the purchasing department's processes (which can be an advantage if you reflect on them and introduce improvements).

\section{Membership in a GPO}

Those some GPOs allow to enter their structures free of charge, members of a GPO generally pay an entrance fee to join. Some GPOs have also a significant annual membership fee requirements. Others cover operating expenses and services through charging either solely manufacturers or both manufactures and GPO members administrative fee (e.g. Windfall, which has 200000 suppliers excluding members [11]) [12], however, these are the administrative fees from manufacturers, which are the main source of GPOs' revenue. An average weighted contract administrative fee of a GPO ranges from $1.22 \%$ to $2.25 \%$ (Schotanus et al., 2010). Based on the information provided by one of the GPOs, about 80-100 percent of its revenue came from manufacturer and distributor administrative fees. The Office of Inspector General, U.S. Department of Health and Human Services noted, however, that GPOs' revenues from vendor fees substantially exceeded operational costs. In its 2005 review of three GPOs, the OIG found that the GPOs collected administrative fees of $\$ 1.8$ billion for the time periods reviewed. Of this amount, the OIG found that $\$ 1.3$ billion, or 72 cents of every dollar collected, represented net revenue in excess of operating costs. The remaining $\$ 487$ million, or 27 cents of every dollar collected, was used to cover the GPOs' operating costs. About $70 \%$ of the excess revenue was distributed to members and the rest was retained by the GPOs, mainly to provide reserves and venture capital for new business lines [13].

Additional sources of financing operations of a GPO are:

- central invoicing (one unit makes a transaction on behalf of the whole) and redirecting orders to group members;

- sales of goods;

- and other services for partners.

In practice statutory fees as well as commissions depend on the sector of activity. In Poland it is usually between 20 and 200 zloty monthly and a commission from a supplier's broker which amounts to $1-5 \%$. For instance, the PPO Passa charges 20 zloty fee and $1 \%$ of the takeover worked out by group [14].
GROUP PURCHASING ORGANIZATION (GPO)

Joanna

Piorunowska-Kokoszko 
GROUP PURCHASING ORGANIZATION (GPO)

Joanna

Piorunowska-Kokoszko

Figure 1.

The average of purchasing cost reduction in 11-months

Figure 2.

The reduction in the lead time from suppliers

\section{Benefits of a GPO}

Entering purchasing group organizations is usually financially viable, because it contributes to savings on the part of its participants. For instance, the English OBN Purchasing Consortium shows in their Savings Analysis that their fifty member companies have saved over $£ 3$ million in last two years, which meant that each of the companies belonging to the GOP economized $4.5 \%$ per each purchased item [15]. What is more, the research of H. Ghaderi and Z. Leman of the year 2013 (Ghaderi and Leman, 2013) shows that many firms managed to reduce their purchasing prices by 7.4 to $12.5 \%$ (an average cost of the purchasing price for all the members of union in the last 11 - months is shown in Figure 1). It is interesting to learn that the data presented by the researchers was collected over two periods, i.e. before setting up the purchasing consortia and after inauguration of their activities. The first batch was collected over 5 months of the regular operation by direct contact with firms by means of quantitative questionnaires, while the other amassed over 6 months through direct contact with the purchasing consortia responsible for the procurement of orders.

It is worth underlying that the results of H. Ghaderi and Z. Leman's research (Ghaderi and Leman, 2013) show an average reduction of $8 \%$ in comparison to the period of before collaboration. Moreover, in terms of delivery time of orders from
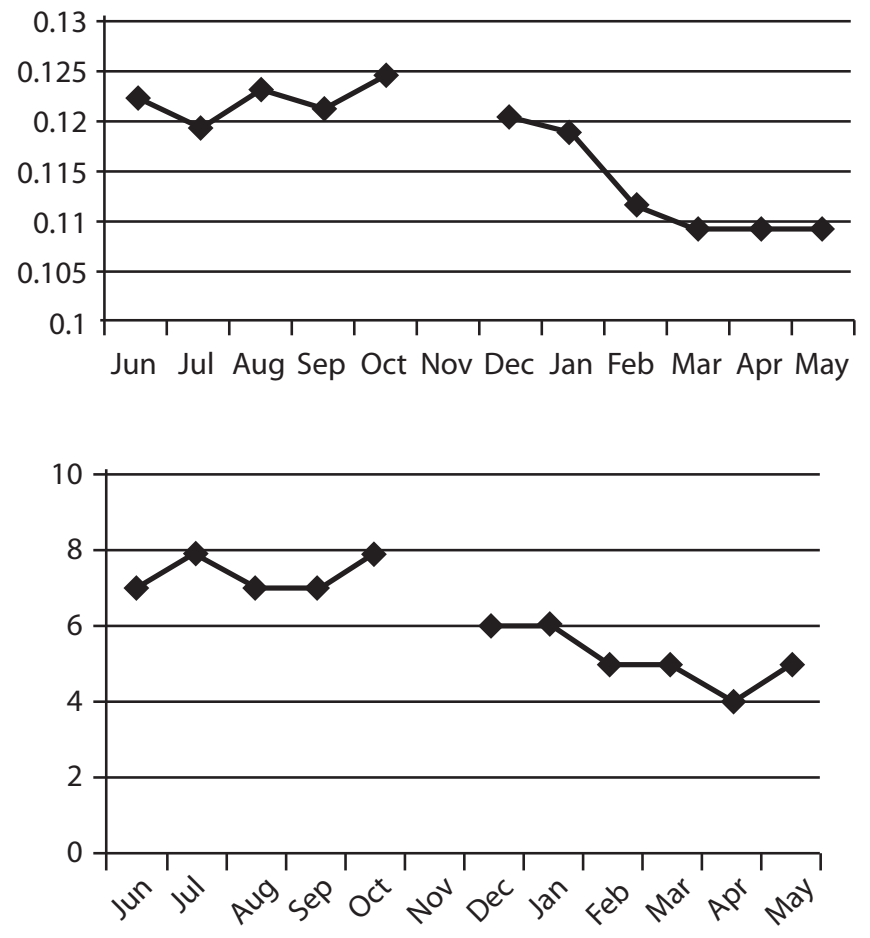
domestic suppliers, the lead-time was reduced from average 8 down to 6 days per each particular raw material type. The researchers also conclude that the success of horizontal collaboration in purchasing cannot be achieved without building trust within the GPO and its effective supervision. Moreover, reduced purchasing costs and shorter lead-time are considered by them to be direct consequences of this cooperation. So are smaller volumes of inventory, well-conditioned raw materials, and customized orders.

The research carried out by W.O. Cleverly and P.C. Nutt (Cleverly and Nutt, 1984), using average relative price paid as the measure, also indicates that companies which entered group purchasing organizations tend to perform better than those which did not. The results show that the percentage of savings per each purchasing group was sizable, and ranged from 12 up to $25 \%$. Similarly E.S. Schneller's study (Schneller, 2009) estimates that GPOs save the U.S. health care industry $\$ 36$ billion dollars annually in price savings and over $\$ 2$ billion dollars in savings associated with human resources uncommitted to the purchasing process. The success of partnership with w GPO has been also proved by T. Hendrick's research. According to his study, organizations participating in purchasing consortia reported that buying through the organizations led to savings amounting to approximately $13.4 \%$, which yielded average annual savings assessed at about $\$ 2.3$ million for each member [16]. S. Khalid's research (Khalid, 2014) shows that between 15 and $21 \%$ of 1000 companies have discovered that they can increase savings by up to $10 \%$ simply by using a GPO. Moreover, according to the American Healthcare Supply Chain Association (HSCA), GPOs involved in the sector generated up to $\$ 55$ billion savings in the year 2014. The report specifically maintains that, from 2013 to 2022, GPOs are expected to bring savings of up to $\$ 864$ billion for the entire U.S. health system, $\$ 229$ billion in Medicare savings, and $\$ 169$ billion in Medicaid savings [17].

Encouraging for the participation in GPOs are also findings of research into the Polish market conducted in May 2014 by the Audytel company in the cooperation with the Association of Polish Districts and the Association of Polish Cities. The results of the analysis proved that Polish cities, using GPOs, paid $15.4 \%$ less for electricity than the authorities which did not enter such schemes. It has turned out that local self-government bodies acknowledge benefits especially in their negotiating the price of electricity. In 2013, 46.5\%, of them used GPOs in this transaction, while in the year 2014 this number grew up to $60.3 \%$ (Bernatek and Konarzewski, 2013). The first enrollment for the purchasing consortium established by the Association of Entrepreneurs and Employers enabled its participants to negotiate a $35 \%$ discount on electricity. Given the fact that an average consortium member used to pay monthly PLN 500 for the electricity, and having in mind that its joining a GPO has reduced its expenses to circa 350 PLN, average annual savings amount to PLN 2000 [18]. Savings are also confirmed by

GROUP PURCHASING ORGANIZATION (GPO)

Joanna

Piorunowska-Kokoszko 
GROUP PURCHASING ORGANIZATION (GPO)

Joanna

Piorunowska-Kokoszko

Table 1. Electricity cost reduction in GPO

Table 2.

Business Club Group Savings in 2013 research conducted by the Logistics and Storing Institute (ILIM) in the FMCG sector. According to the published data companies participating in GPOs were able to claim a $7 \%$ discount on costs of energy (Table 1 ).

\begin{tabular}{|c|c|c|}
\hline \multicolumn{2}{|l|}{ Number of companies } & 8.00 \\
\hline \multicolumn{2}{|c|}{ Quantity of used electricity (kWh) } & 9158.91 \\
\hline \multicolumn{2}{|c|}{ Cost of electrycity (PLN) } & $\begin{array}{r}2361 \\
534.00\end{array}$ \\
\hline \multirow{3}{*}{$\begin{array}{l}\text { Cost calculation of } \\
\text { GPO }\end{array}$} & Cost of electrycity (PLN) & $\begin{array}{r}2220 \\
358.00\end{array}$ \\
\hline & Savings (PLN) & 157956.00 \\
\hline & $\%$ of cost reduction & $7 \%$ \\
\hline
\end{tabular}

Optimistic results have been also made public by the Business Club Group, showing that the organization plans to augment the number of their members in pursuit of stimulating savings figures, which currently average at $2.5 \%$ on petrol and $35 \%$ on delivery services (Table 2 ).

\begin{tabular}{lll}
\hline \multicolumn{1}{c}{ Group } & \multicolumn{1}{c}{ Savings } & \multicolumn{1}{c}{ Other } \\
\hline Electric energy & $6 \%-6000000$ PLN & $\begin{array}{l}\text { 87 firms, 400-500 GWh } \\
(100000000 \text { PLN })\end{array}$ \\
\hline Patrol & $2.5 \%-2500000$ PLN & 113 firms, 110 000 000 PLN \\
\hline Delivery services & $35 \%-700000$ PLN & 37 firms, 2 000 000 PLN \\
\hline Office supplies & $6 \%-135000$ PLN & $\begin{array}{l}34 \text { firms, 2 000 000 PLN } \\
\text { per year }\end{array}$ \\
\hline
\end{tabular}

It should be also underscored that the afore-mentioned savings are not the only benefit of joining a GPO structure. Research of G. Zimon (Zimon, 2013) shows that such a decision has no adverse impact on financial statements either, since, due to longer payment deadlines, the activity of GPOs does not cause a rise in liabilities of companies. G. Zimon (Zimon, 2013) has proved that an average level of the total debt indicator of a company belonging to the GPO should be assessed at 0.56 . The figure confirms operating safety of the companies and their conservative politics in respect of managing their sources of finances. An additional analysis shows that $90 \%$ of the companies' liabilities are short-term and that their conditions have been negotiated through purchasing groups.

Above presented results of different activities of group purchasing organizations were confirmed by my own research in one of Polish purchasing Group - KOMANDOR. KOMANDOR is one of the most renowned in Poland 
manufactures of sliding doors and customized furniture. The firm was set up in 1992 and its dynamic growth has led its management to seek to optimize its activities on the competitive global market. As a result, in March of 2011 a KOMANDOR purchasing group was created to become a holding of 16 medium-size enterprises belonging to one brand.

Research was conducted by the author of this article into the KOMANDOR purchasing group on the basis of main parameters included in other academic reports, i.e.

- purchase prices;

- lead time from suppliers;

- and, additionally, other benefits negotiated in the contracts by the purchasing group.

The analysis concerns the year preceding the creation of the group and subsequently on the results reported in the first and second year of its work, since the concern made public figures for the years 210-2012.

The first point of research was concerned with observable changes in purchase prices. It has turned out that activities of the purchasing group led to a reduction of average buying prices by $14 \%$ in the first and by $10 \%$ in the second year, while the drop was not uniform, influenced by the strategy of a supplier and modified by the provider's expectations of other benefits from the cooperation with KOMANDOR. The decrease in prices was more prominent in the first year is thought to be a result of the scale effect. Accordingly, it was less perceivable in the second year and the rate of the process of economies acquisition for KOMANDOR is expected to be limited in the following years (Table 3, Figure 3).

\begin{tabular}{|c|c|c|c|c|c|c|c|}
\hline & \multicolumn{3}{|c|}{$\begin{array}{l}\text { Average unit netto } \\
\text { price (PLN) }\end{array}$} & \multirow{2}{*}{$\begin{array}{c}\text { Quantita- } \\
\text { tive change } \\
2011 / 2010\end{array}$} & \multirow{2}{*}{$\begin{array}{l}\text { Percenta- } \\
\text { ge change } \\
2010 / 2011\end{array}$} & \multirow{2}{*}{$\begin{array}{l}\text { Quantita- } \\
\text { tive change } \\
2012 / 2011\end{array}$} & \multirow{2}{*}{$\begin{array}{l}\text { Percentage } \\
\text { change } \\
\text { 2012/2011 }\end{array}$} \\
\hline & 2010 & 2011 & 2012 & & & & \\
\hline \multicolumn{8}{|l|}{ Laminated panel } \\
\hline Egger & 29.31 & 23.44 & 21.12 & -5.87 & $-20 \%$ & -2.32 & $-9.90 \%$ \\
\hline Kronopol & 24.13 & 23.9 & 23.15 & -0.23 & $-1 \%$ & -0.75 & $-3 \%$ \\
\hline \multicolumn{8}{|l|}{$\begin{array}{l}\text { Furniture } \\
\text { accessories }\end{array}$} \\
\hline Hettich & 15.25 & 11.52 & 10.98 & -3.73 & $-24 \%$ & -0.54 & $-5 \%$ \\
\hline \multicolumn{8}{|l|}{ Edging PCV } \\
\hline Dollken & 1.25 & 1.19 & 0.95 & -0.06 & $-5 \%$ & -0.24 & $-20 \%$ \\
\hline $\begin{array}{l}\text { Average change } \\
\text { of prices }\end{array}$ & 11.66 & 10.01 & 9.37 & -1.65 & $-14 \%$ & -0.96 & $-10 \%$ \\
\hline
\end{tabular}

GROUP PURCHASING ORGANIZATION (GPO) Joanna Piorunowska-Kokoszko

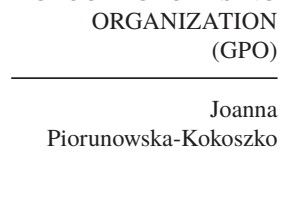


GROUP PURCHASING ORGANIZATION

(GPO)

Joanna

Piorunowska-Kokoszko

Figure 3. Average change of prices in KOMANDOR 2010-2012

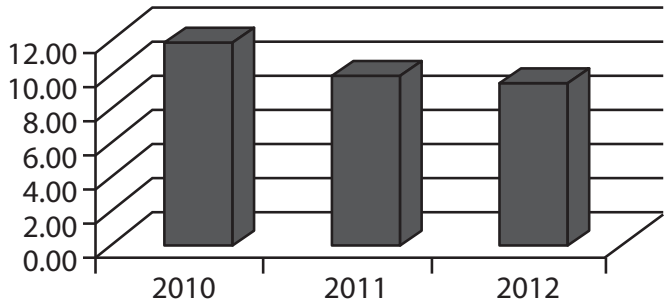

Average change

of prices

The second aspect of the analysis included a comparison of lead time form supplies, i.e., rate at which deliveries were made. Results of the research show that the activity of the group also contributed to the shortening of delivery schedules, Accordingly, figures for the first year demonstrate a reduction of 5.34 days in delivery duration, while for the second they indicate an economy of 1.29 days. The average delivery period was calculated as an arithmetic average of delivery duration and the volume of delivery over the researched period. The delivery duration has been defined as the period from the moment of placing an order with the supplier up to time of the arrival of the goods at the buyer's warehouse, and rounded to full days (Table 4, Figure 4).

Table 4.

Reduction of lead time from purchasing in Komandor Purchasing Group 2010-2012

\begin{tabular}{|c|c|c|c|c|c|c|c|}
\hline & \multicolumn{3}{|c|}{$\begin{array}{l}\text { Average lead time } \\
\text { (in days) }\end{array}$} & \multirow{2}{*}{$\begin{array}{l}\text { Quantita- } \\
\text { tive change } \\
2011 / 2010\end{array}$} & \multirow{2}{*}{$\begin{array}{c}\text { Percentage } \\
\text { change } \\
2010 / 2011\end{array}$} & \multirow{2}{*}{$\begin{array}{l}\text { Quantita- } \\
\text { tive change } \\
2012 / 2011\end{array}$} & \multirow{2}{*}{$\begin{array}{c}\text { Percentage } \\
\text { change } \\
2012 / 2011\end{array}$} \\
\hline & 2010 & 2011 & 2012 & & & & \\
\hline \multicolumn{8}{|l|}{ Laminated Panel } \\
\hline Egger & 17.75 & 6.25 & 6.15 & -11.5 & $-65 \%$ & -0.10 & $-1.60 \%$ \\
\hline Kronopol & 3.92 & 1.75 & 1.55 & -2.17 & $-55 \%$ & -0.20 & $-11 \%$ \\
\hline \multicolumn{8}{|l|}{$\begin{array}{l}\text { Furniture } \\
\text { Accessories } \\
\end{array}$} \\
\hline Hettich & 22.75 & 12 & 7.16 & -10.75 & $-47 \%$ & -4.84 & $-40 \%$ \\
\hline \multicolumn{8}{|l|}{ Edging PCV } \\
\hline Dollken & 14.67 & 7.08 & 7.05 & -7.59 & $-52 \%$ & -0.03 & $0 \%$ \\
\hline $\begin{array}{l}\text { Average of lead } \\
\text { time from } \\
\text { suppliers }\end{array}$ & 9.85 & 4.51 & 3.65 & -5.34 & $-54 \%$ & -1.29 & $-35 \%$ \\
\hline
\end{tabular}




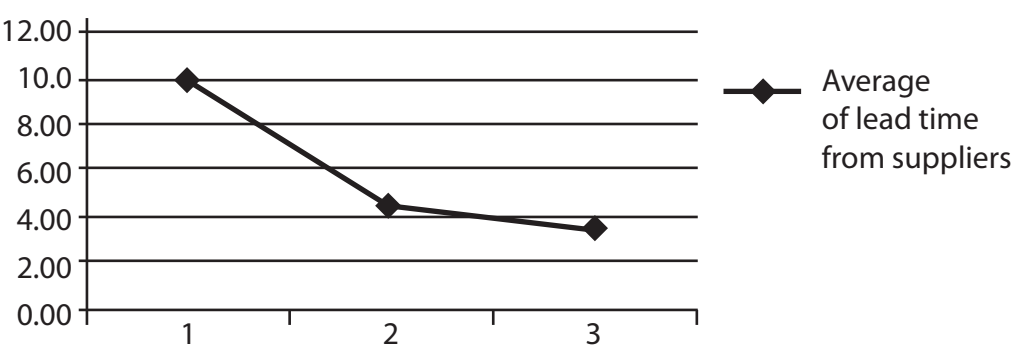

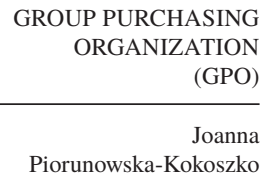

Figure 4. Change of lead time from suppliers in KOMANDOR 2010-2012

As a result of building relations of the KOMANDOR purchasing group with its suppliers, and on top of contractual terms, the holding has achieved a prolongation of payment for the concern up to 60-90 days and additional marketing support from key suppliers. Consequently, the KOMANDOR purchasing group secured from its suppliers subsidies of 428567.40 PLN, which supported the concern's marketing campaigns conducted between 2011 and 2012 (Figure 5).

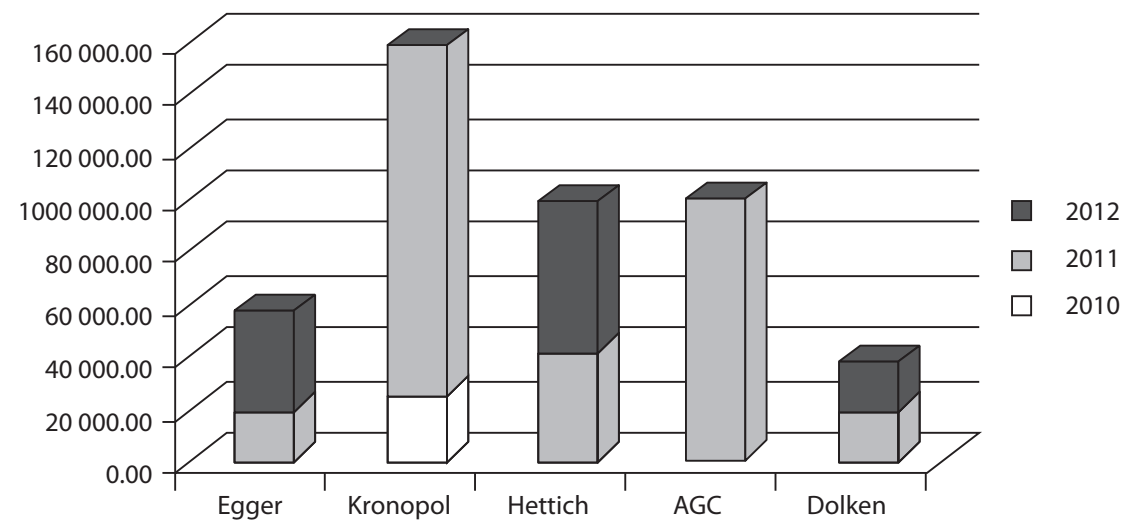

Figure 5. Marketing support for KOMANDOR from suppliers 2010-2012

In order to sum up the research presented above, I should come to the conclusion that GPOs are an interesting option in companies' pursuit of operational cost reduction since they are generally effective and do not generate sizeable expenses on the part of participating companies. Therefore it should be concluded that we can expect a permanent increase in the number of GPOs in the future both internationally and nationally. A purchasing group increases volume consolidation, making it possible to have only one negotiation, in order to increase the purchasing group members' power vis à vis that of its suppliers. However, a purchasing group also constitutes an additional link in the supply chain and 
GROUP PURCHASING ORGANIZATION (GPO)

Joanna

Piorunowska-Kokoszko its objectives could go contrary to those of some of its members. This is why organizations considering joining a purchasing group should analyze this option strategically, in order to assess correctly the potential long term benefits (Nollet and Beaulieu, 2005). Consequently, and the issue requires further research, the success of GPOs cannot be achieved unless building trust and supervision systems within its structure, which are a conditio sine qua non of effectively managing a purchasing group.

\section{Notes}

[1] Originated in the USA, "sharing economy" is a new trend in economy involving direct exchange of goods and services between consumers, communicating via dedicated internet services. It is thought to be a consequence of eagerness, characteristic of a society tired of the recent economic crisis and focused on possessing goods, to implement the idea of mutual sharing.

[2] Purchasing Consortia, The Emerging Collective, available at: http://www.esourcingwiki.com/ index.php/Purchasing_Consortia (accessed 20 May 2015).

[3] Global Purchasing Group, available at: http://www.globalpurchasinggroup.com/ (accessed 11 November 2014).

[4] Colate World of Care Procurement Group

available at: http://www.colgate.com/app/Colgate/US/Corp/ContactUs/GMLS/HomePage.cvsp (accessed 11 November 2014).

[5] Siedzieniewski, M., How to take the risk, available at: http://www.miesiecznikdealer.pl/index. php?menu=glowna\&podmenu=czytaj_artykul\&id=43

(accessed 11 November 2014).

[6] Najlepsze praktyki zakupowe w biznesie, czyli jak i ile mogą zaoszczędzić szpitale?, available at: http://www.termedia.pl/f/f/688166bb9e0f8b83953b37e07163140d.pdf (accessed 19 November 2014).

[7] Grupy zakupowe, available at: http://mtm-learning.com.pl/ct-menu-item-42/grupy-zakupowe (accessed 20 April 2015).

[8] Asia Pacific Utilities Group, available at: http://www.apug.com (accessed 11 November 2014).

[9] Pierwsze Grupy Zakupowe B2B w Polsce, available at: http://www.batnagroup.pl/\#O\%20nas (accessed 20 April 2015).

[10] Magnuszewska, A. (2015), "Łódzka Grupa Zakupowa. Łódź oszczędziła na prądzie $8 \mathrm{mln}$ zł”, Dziennik Łódzki, available at: http://www.dzienniklodzki.pl/artykul/3779083,lodzka-grupazakupowa-lodz-oszczedzila-na-pradzie-8-mln-zl,id,t.html (accessed 20 April 2015).

[11] Get windfall, available at: http://getwindfall.com/ (accessed 22 May 2015).

[12] Sadler, D. (2012), "How Group Purchasing Can Mean Big Savings for Small Businesses", available at: http://www.allbusiness.com/how-group-purchasing-can-mean-big-savings-for-smallbusinesses-15037283-1.html (accessed 22 May 2015).

[13] Office of Inspector General, U.S. Department of Health and Human Services, supra note 11.

[14] Sieci franczyzowe i grupy zakupowe mają swoje wady i zalety, available at: http://forsal. pl/artykuly/726407,siec-franczyzowa-grupa-zakupowa-wady-zalety.html (accessed 28 November 2014).

[15] OBN: Supprting Emerging Life Sciences Companies, available at:

http://www.obn.org.uk/purchasing-consortium/ (accessed 27 May 2015).

[16] Consortia, Buying Groups and Trends in Demand Aggregation Keven Gray, VP Corporate Strategy.

[17] Group Purchasing Organizations generate \$55 Billion in annual cost savings, available at: 
http://nebraskaruralhealth.org/2014/07/group-purchasing-organizations-generate-55-billion-inannual-cost-savings/ (accessed 22 May 2015).

[18] Tańszy prąd? Tylko w grupie zakupowej, available at: http://www.forbes.pl/tanszy-prad-dlafirm-w-grupach-zakupowych, artykuly,164715,1,1.html (accessed 25 May 2015).

\section{References}

Aigrain, P. (2012), Sharing: Culture and economy of the Time of Internet, Amsterdam University Press, Amsterdam.

Arend, R.J., Wisner, J.D. (2005), "Small Business and Supply Chain Management: Is There a Fit?", Journal of Business Venturing, Vol. 20 No. 3, pp. 403-436. DOI: http://dx.doi.org/10.1016/j.jbusvent.2003.11.003

Bartkowiak, P., Domański, J. (2013), "Szpitalne Grupy Zakupowe w kształtowaniu łańcucha wartości na rynku usług szpitalnych", Przedsiębiorczość i Zarzqdzanie, Vol. XIV No. 3, pp. 15-25.

Bernatek, G., Konarzewski, E., (2013), "Efektywność zakupu energii elektrycznej w Jednostkach Samorządu Terytorialnego. Raport z badania przeprowadzonego w współpracy ze związkiem powiatów polskich", Dział Badań $i$ Analiz Audytel S.A., available at: http://www.audytel.pl/wp-content/uploads/2013/06/Rapot_Badanie-efektywnosci-zakupu-energii-w-JST_Leaflet_20136029.pdf (accessed 22 May 2015).

Burns, L.R. (2002), The Helth Care Value Chain, Jossey-Bass, San Francisco.

Cleverley, W.O., Nutt, P.C. (1984), "The Effectiveness of Group-Purchasing Organizations", Health Services Research, Vol. 19 No. 1, pp. 65-81.

Doliński, D. (2013), “Opracowanie koncepcji oraz zadadności wdrożenia grupowych zakupów przez Klaster Spożywczy Południowej Wielkopolski”, available at: http:// slideplayer.pl/slide/812827 (accessed 22 May 2015).

Essig, M. (2000), "Purchasing consortia as symbiotic relationships: developing the concept of "consortium sourcing"”, European Journal of Purchasing \& Supply Management, Vol. 6 No. 1, pp. 13-22. DOI: http://dx.doi.org/10.1016/S0969-7012(99)00031-3

Ghaderi, H., Leman, Z. (2013), "Horizontal collaboration in purchasing: A successful case from small and medium enterprises (SMEs)", African Journal of Business Management, Vol. 7 No. 10, pp. 750-753. DOI: http://dx.doi.org/10.5897/AJBM10.916

Gray, K. (2002), "Consortia, Buying Groups and Trends in Demand Aggregation”, VP Corporate Strategy, Corporate United, available at: https://www.instituteforsupplymanagement.org/files/Pubs/Proceedings/GrayEI.pdf (accessed 22 May 2015).

Hong, P., Jeong, J. (2006), "Supply chain management practices of SMEs: from a business growth perspective", Journal of Enterprise Information Management, Vol. 19 No. 3, pp. 292-302.

Kaszyński, W., Federowski, J., Healhcare, J. (2011), “GPO - together”, Healthcare Manager, December-January 10/2011, p. 67.

Khalid, S. (2014), “The True Value of GPOs and Purchasing Consortiums”, Instasupplay, available at: http://www.instasupply.com/posts/2014/10/27/the-true-value-of-gposand-purchasing-consortiums (accessed 22 May 2015).

Knoben, H.K., Sawiński, M. (2014), “Związki zakupowo-marketingowe w Niemczech”,

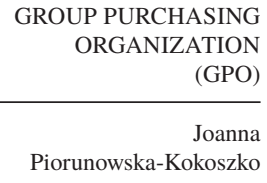

Piorunowska-Kokoszko 
GROUP PURCHASING ORGANIZATION (GPO)

Joanna

Piorunowska-Kokoszko available at: http://www.polishcosmetics.pl/f/images/Zwiazki-zakupowo-marketingowe-w-Niemczech.pdf (accessed 22 May 2015).

Kolińska, K., Doliński, D. (2013), "Grupowe zakupy materiałów jako sposób na obniżenie kosztów przedsiębiorstwa”, Logistyka, Vol. 5/2013, pp. 98-101.

Leddy, E.B. (2002), “Consortium Procurement - A Look Inside”, Inside Supply Management, July 2002, p. 8.

Magnuszewska, A. (2015), "Lódzka Grupa Zakupowa. Łódź oszczędziła na prądzie $8 \mathrm{mln}$ zl”, available at: http://www.dzienniklodzki.pl/artykul/3779083,lodzka-grupazakupowa-lodz-oszczedzila-na-pradzie-8-mln-zl,id,t.html (accessed 20 April 2015).

Nollet, J., Beaulieu, M. (2005), "Should an organization join a purchasing group?", Supply Chain Management: An International Journal, Vol. 10 No. 1, pp. 11-17.

Polychronakis, Y., Syntetos, A. (2007), "Soft supplier management related issues: an empirical investigation", International Journal of Production Economics, Vol. 106 No. 2, pp. 431-449. DOI: http://dx.doi.org/10.1016/j.ijpe.2006.07.008

Sadler, D. (2012), "How Group Purchasing Can Mean Big Savings for Small Businesses", available at: http://www.allbusiness.com/how-group-purchasing-can-mean-big-savingsfor- small-businesses-15037283-1.html (accessed 22 May 2015).

Scanlon, W.J. (2002), "Group Purchasing Organizations: pilot study suggests large buying groups do not always offer hospitals lower prices: testimony before the Subcommittee on Antitrust, Competition, and Business and Consumer Rights", Committee on the Judiciary, U.S. Senate, GAO-02-690T, 30 April 2002, avalible at: http://www.gao. gov/new.items/d02690t.pdf (accessed 22 May 2015).

Schneller, E.S. (2009), "The Value of Group Purchasing - 2009: Meeting the Needs for Strategic Savings", available at: https://www.novationco.com/media/industryinfo/ value_of_gpo_2009.pdf (accessed 22 May 2015).

Schotanus, F., Telgen, J., Boer, L. (2010), "Critical success factors for managing purchasing groups", Journal of Purchasing \& Supply Management, Vol. 16 No. 1, pp. 51-60. DOI: http://dx.doi.org/10.1016/j.pursup.2009.10.002

Tella, E., Virolainen, V.M. (2005), "Motives behind purchasing consortia", International Journal of Production Economics, Vol. 93-94, pp. 161-168. DOI: http://dx.doi. org/10.1016/j.ijpe.2004.06.014

Weinstein, B.L. (2006), "The Role of Group Purchasing Organizations (GPO) in the U.S. Medical Industry Supplay Chain", Estudios De Economia Aplicada, Vol. 24 No. 3, pp. 789-802.

Zimon, G. (2013), “Zarządzanie kosztami w jednostkach tworzących branżowe grupy zakupowe", Zeszyty Naukowe Finanse, Rynki Finanasowe, Ubezpiecznia, Vol. 58/2013, pp. 293-299. 